\title{
A methodology for forecasting hazardous waste flows
}

\author{
J. Vilgerts, L. Timma \& D. Blumberga \\ Institute of Energy Systems and Environment, \\ Riga Technical University, Latvia
}

\begin{abstract}
In previous years, great attention has been paid to the problem of hazardous waste management. "Prevention costs" of the activities concerned with hazardous waste (HW) are lower than "restoration costs" after damage is done. Within the scope of the paper the methodology for forecasting hazardous waste flows was elaborated. The methodology of the research included 6 modules: historical data, assumptions, choose of indicators, data processing, and data analysis with STATGRAPHICS, and forecast models. The proposed methodology was validated for the case for Latvia. A new type of the indicator based on the HW intensity within the Statistical Classification of Economic Activities in the European Community (NACE Rev. 2) sectors and households has been developed. The indicator allows for assessing the HW production intensity. The results of the study suggest that HW intensity in Latvia is forecasted to slowly decrease by $3.8 \%$ in next six years. The pessimistic prognosis (upper 95\%) gives an increase in HW intensity by $44.5 \%$, but the intermediate (upper and lower $50 \%$ ) gives a corridor of $+18.4 \%$ to $-36.1 \%$.

Keywords: hazardous waste, sustainable development, benchmarking, waste management, indicators, forecast models.
\end{abstract}

\section{Introduction}

Waste disposal has vexed societies for centuries; nevertheless, just lately, a rapid growth of the world population, increasing consumerism and, last by not least, the industrial and petrochemical revolutions, has triggered the exponential increase in the amount of waste flows, including hazardous waste (HW) [1]. As a response to growing concerns, the European Union (EU) works on the sticker 
inspections and enforcement of the regulations within the HW sector, as well as on future legislative measures [2]. About 77 million tonnes of HW were generated only within the European Union 27 member states (EU-27) in the year 2009. From the year 2000 until 2008 the amount of HW in the EU-27 has increased by $46 \%$, followed by $8 \%$ decrease in 2009 . Nevertheless, on average $154 \mathrm{~kg}$ of HW were generated per capita within EU-27 in the year 2009 and the Eurostat estimates increase by up to $198 \mathrm{~kg}$ of HW per capita in the year 2010 [2]. The report by the European Environmental Agency (EEA) also states that waste (also hazardous) prevention goal of the $6^{\text {th }}$ European Action Program (EAP) have not been achieved [3]. In order to propose measures for the reduction of the amount of $\mathrm{HW}$ and to monitor and analyse the results, the indicative values should be introduced within the sector. The researches previously done on the introduction of indicators for the HW sector can be classified as qualitative and quantitative ones. The qualitative assessment of HW flows is given in the research by Weltens et al. [4]. The authors presented an alternative methodology for the hazard categorization of complex waste matrices. The developed methodology is in line with the principles of the waste classification given in the Hazardous Waste Directive [5], but proposes to substitute the tests of the risk assessment performed on animals with the tests on cellular mechanisms. The usage of microorganisms in order to define eco-toxicological potential is studied by Wilke et al. [6]. The application of biomarkers for the detection of low levels of HW is described by Giusti [7] In order to perform both qualitative and quantitative analysis, an integrated fuzzy hazardous waste index for the composite materials is studied by Musee et al. [8-10]. By application of the fuzzy algorithm the final aggregated hazard index was obtained. The study gives results on the fuzzy algorithm application for9 hypothetical examples. Das et al. [11] proposed the composite hazardous waste index and hazard potential, which allows the comparison of various streams of industrial waste. The quantitative weight-based indicators for HW were studied by Elimelech et al. [12]. The proposed indicators referred either to raw material (the amount of HW according to the amount of crude oil processed), final product (the amount of HW according to the weight of dry cleaned clothes), or service supplied (the amount of HW according to the beds occupied in hospital). Moreira and Gunther [13] used the weight based indicators for the assessment of effectiveness of waste management strategy in health care centres. Kiurski et al. [14] identified HW substances in printing industry. The authors used concentration based indicators in order to define the target levels for volatile organic components (55.72 ppm for $8 \mathrm{~h}$ working time).Yuan [15] proposed implementation of 30 indicators in order to describe the effectiveness of construction and demolition waste management system. The methodology for the assessment of ecological footprint for HW is presented by Herva et al. [16]. Streimikiene [17] converted the amount of the nuclear waste produced into the costs of nuclear waste storage. Thus, the two possible greenhouse gas mitigation options in Lithuania were compared: nuclear power and carbon capture and storage. Economic activity is used as an indicator in the waste sector. The amount of HW to be a function of the economic activity in the country and region is pointed out in the report of 
European Commission [2]. Sixth EAP defines that use of resources and waste generation should be decoupled from economic growth. The Directive 2008/98/EC on waste [18] sets the objectives for the proposed targets. The report by EEA [3] states that depending on the type of waste analysed the amount of waste is stabilizing or continues to grow, but at lower rate than gross domestic product (GDP). Forecast models of the HW amounts are mainly based on the economic activity indicators. Mazzanti [19], Mazzanti and Zoboli [20] showed that no absolute delinking trends between waste generation and GDP are present in the EU-27. Sjöström and Östblom [21] based the forecast of the HW amount in Sweden on a Computable General Equilibrium model of the economy developed by Sjöström and Östblom [22]. While the amount of non-hazardous waste showed decoupling for 11 out of 17 cases, the total amount of the HW was predicted to grow faster than GDP. Third order regression model between the generation of industrial solid wastes and GDP per capita was developed by Yanrong et al. [23] with $\mathrm{R}^{2}=0.99$. The research done by Lilja and Liukkonen [25] suggests usage of the waste generation in specific sector rather than GDP. Court [26] analysed the economy and HW generation in the United States of America by using hazardous waste generation intensity indicator (tons $/ \mathbf{\$ M}$ ). The author found out that highest intensity of HW generation belong to chemical products, waste management and remediation services, primary metals and petroleum and coal products industries. Based on the European Commission report [24] the largest implementation gaps for municipal waste management were observed in 12 member states, including Latvia. The report pointed out poor quality of forecast quality, which refers to the inadequate capacity of waste management facilities. The waste management plan for Latvia 2013-2020 [27] proposes following indicators to assess the performance of $\mathrm{HW}$ management strategy: the total amount of HW produced during one year, the percentage of recycled $\mathrm{HW}$ as $75 \%$, and percentage of landfilled $\mathrm{HW}$ no more than $25 \%$ until 2020.At the same time waste management plan forecasts $25 \%$ increase in HW production from 2010 until 2020.

\section{Methodology}

\subsection{Algorithm of methodology}

The methodology consists of data analysis by STATGRAPHICS based on the HW intensity within the Statistical Classification of Economic Activities in the European Community (NACERev. 2) sectors and households and forecast models, with 6 modules: historical data, assumptions, choose of indicators, data processing, and data analysis. Using historical data in the proposed algorithm it is possible to forecast HW flows in various sectors (see Figure 1).

\subsection{The module of the historical data}

Historical data about the amounts of HW has been taken from the State limited Liability Company "Latvia Environment, Geology and Meteorology Centre" 


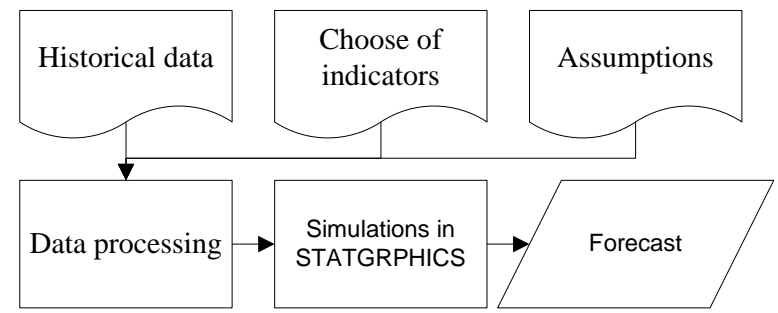

Figure 1: The algorithm of the methodology.

database Nr.3-Waste [28]. Yearly management of the statistical data on the HW is done by the Centre. Based on the Republic of Latvia Cabinet Regulation No.1075 [29], the data about generated amounts of HW should be submitted by all operators who have obtained the A and B polluting activities permits and also operators with the permits for waste management. The information available in the database is divided by sectors based on the NACE Rev. 2 classification. NACE Rev. 2, which is the statistical classification of economic activities in the European Communities [28]. The amount of generated HW within NACE Rev. 2 sectors is subtracted from the total amount of HW and the difference is assumed to be generated by the households. Data about the Gross Domestic Product (GDP) is divided by sectors based on the NACE Rev. 2 classification and is chain-linked reference for the year 2000.

\subsection{The module of the assumptions}

In the paper it is assumed that all flows of HW are collected and properly managed. It is assumed that difference between total amount of GDP and GDP produced within NACE sectors is accounted for the households.

\subsection{Data processing module}

The NACE Rev. 2 sectors, which accounted for less than 1\% impact to the total flow of HW within all NACE Rev. 2 sectors were merged together and named as "Other" or "Other NACE sectors". The data about the total amount of HW was divided by the amount of GDP for each individual sector and households, so the HW intensity indicators were obtained. The indicative values were calculated for a period of eight years (2003-2010).

\subsection{Simulation module in STATGRAPHICS}

The interactive statistical data analysis tool STATGRAPHICS Centurion 16.1.15 was used to construct forecast models based on the obtained indicative values for selected NACE Rev. 2 sectors and households. The simulation module within the STATGRAPHICS tool provided analysis for over 13 possible models. The root mean squared error (RMSE), the mean absolute error (MAE) and the mean absolute percentage error (MAPE) were set as the target functions for the optimization of the forecast model. The confidence level of the forecast models 
has been set to the $95.0 \%$. Forecasts were built for the period of 2011-2016 at a confidence level of $95 \%$ and $50 \%$.

\section{Results}

\subsection{Indicator analysis}

The values of the HW intensity indicator for NACE Rev.2 sectors and households for Latvia in 2010 are given in Figure 2.

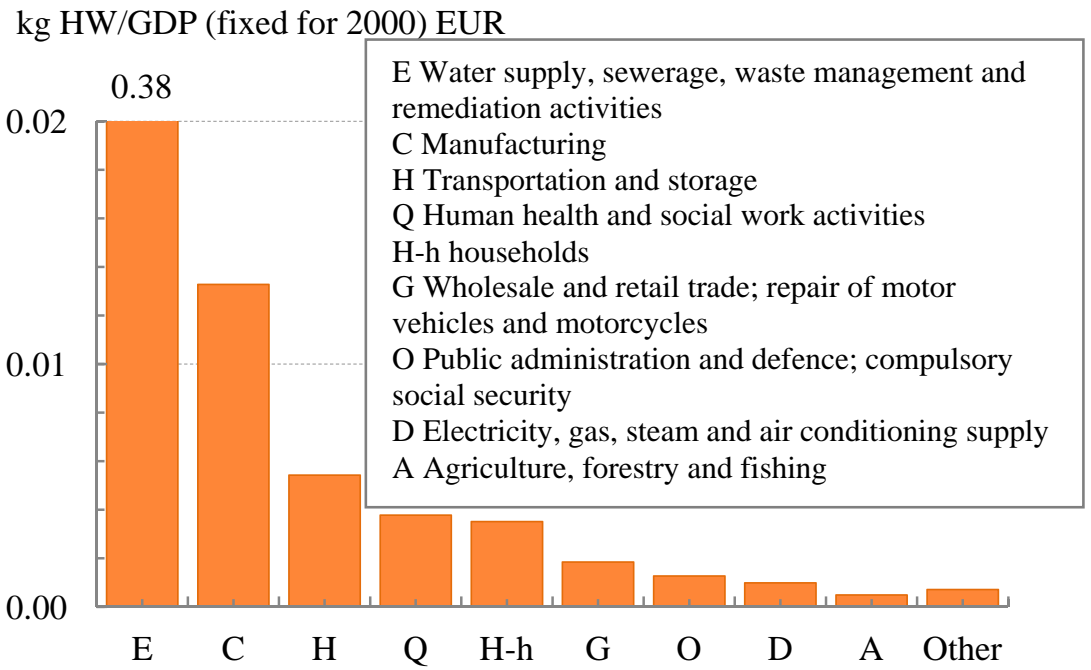

Sectors as given in NACE Rev 2 and households

Figure 2: Value of the indicator for sectors according to the NACE Rev. 2 and households where "Other" includes B Mining and quarrying; F Construction; I Accommodation and food service activities; J Information and communication; L Real estate activities; M Professional scientific and technical activities; N Administrative and support service activities; P Education; R Arts, entertainment and recreation; $\mathrm{S}$ Other service activities.

\subsection{Example of the forecast model}

Table 1 summarizes statistical significance of the selected forecasting models and performance of the currently selected model in fitting the historical data.

For example, the simulation module has forecasted the future values of Sector $\mathrm{C}$, to be expressed by an autoregressive integrated moving average (ARIMA) $(1,2,1)$ model. The general model of ARIMA (p, d, q) is represented by ARIMA $(1,2,1)$. Where $p$ is number of non-seasonal autoregressive terms, $\mathrm{d}$ is the number of non-seasonal differences, and $\mathrm{q}$ is the number of lagged 
forecast errors in the prediction equation. The mathematical expression of the general model of ARIMA $(1,2,1)$ is given in eqn (1).

$$
\begin{aligned}
& \operatorname{ARIMA}(1,2,1)=\hat{Y}(t)=2 Y(t-1)+Y(t-2)+ \\
& \quad+\phi[Y(t-1)-Y(t-2)]-\theta e(t-1)
\end{aligned}
$$

where $\hat{Y}(t)$ is the result for the times series, $\phi$ is non-seasonal differencing and $\theta$ is non-seasonal lagged forecast error, and $(t-1)$ and $(t-2)$ are time periods.

Table 1: $\quad$ Summary for the forecast models.

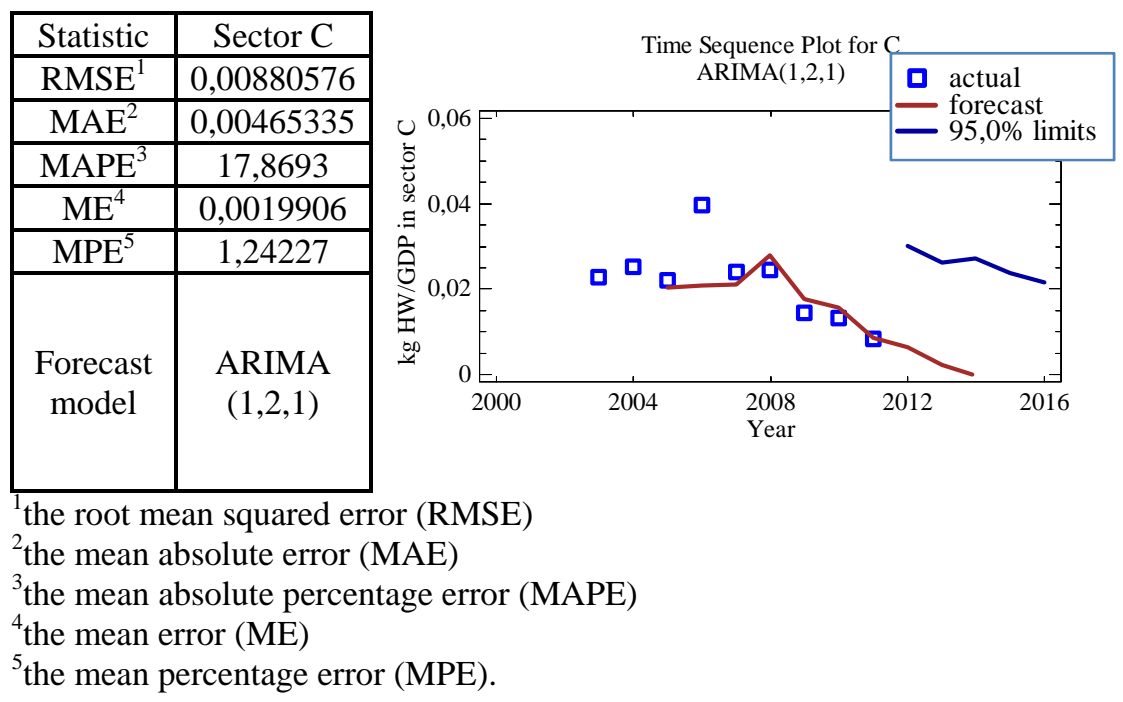

\subsection{Model summary}

Table 1 gives the description for the selected forecast models. Table 2 gives the possibility to reproduce the forecast models for each of the analysed sectors.

\section{Discussion}

Figure 3 gives the summary of the forecast model for all studied NACE sectors and households in Latvia. The upper limits for 95\% confidence level and the both upper and lower limits for 50\% confidence level are given in Figure 3.

The results of the study suggest that HW intensity in Latvia is forecasted to slowly decrease by $3.8 \%$ in the next six years. The pessimistic prognosis (upper $95 \%$ ) gives an increase in $\mathrm{HW}$ intensity by $44.5 \%$, but intermediate (upper and lower $50 \%$ ) gives a corridor of $+18.4 \%$ to $-36.1 \%$. Within the study a new type of HW intensity indicator has been developed. The proposed indicative value allows us to forecast the changes of the HW intensity within the individual 
Table 2: $\quad$ Model summary.

\begin{tabular}{|c|c|c|c|c|c|c|}
\hline $\begin{array}{l}\text { NACE } \\
\text { sector }\end{array}$ & Parameter & Estimate & Standard error & t-statistic & P-value & $\begin{array}{c}\text { Estimated } \\
\text { white noise } \\
\sigma \\
\end{array}$ \\
\hline \multirow{2}{*}{ Sector A } & $\mathrm{MA}(1)$ & 0,29413 & 0,302423 & 0,972577 & 0,375432 & \multirow{2}{*}{0,0009055} \\
\hline & $\mathrm{MA}(2)$ & 0,854793 & 0,314786 & 2,71547 & 0,042002 & \\
\hline \multirow{2}{*}{ Sector C } & $\mathrm{AR}(1)$ & $-0,69437$ & 0,0641894 & $-10,8175$ & 0,000117 & \multirow{2}{*}{0,0092095} \\
\hline & $\mathrm{MA}(1)$ & 1,16678 & 0,186253 & 6,2645 & 0,001521 & \\
\hline \multirow{2}{*}{ Sector D } & Constant & $-6,64321$ & 0,278919 & $-23,8177$ & 0,000000 & \multirow{2}{*}{ - } \\
\hline & Slope & 2,49112 & 0,638327 & 3,90258 & 0,007960 & \\
\hline Sector E & \multicolumn{5}{|c|}{ Exponential smoothing $(\alpha=0,9999)$} & - \\
\hline \multirow{2}{*}{ Sector G } & $\mathrm{AR}(1)$ & $-0,63536$ & 0,0757115 & $-8,39179$ & 0,000394 & \multirow{2}{*}{0,00074683} \\
\hline & $\mathrm{MA}(1)$ & 1,10133 & 0,119615 & 9,20731 & 0,000254 & \\
\hline \multirow{2}{*}{ Sector H } & $\mathrm{AR}(1)$ & 0,249172 & 0,308014 & 0,808965 & 0,449416 & \multirow{2}{*}{0,00082899} \\
\hline & $\mathrm{AR}(2)$ & $-1,11834$ & 0,256282 & $-4,36369$ & 0,004751 & \\
\hline Sector O & MA(1) & $-0,24064$ & 0,489822 & $-0,49128$ & 0,638257 & 0,0007621 \\
\hline \multirow{2}{*}{ Sector Q } & $\mathrm{AR}(1)$ & 0,302719 & 0,421657 & 0,717927 & 0,499789 & \multirow{2}{*}{0,001372} \\
\hline & $\mathrm{AR}(2)$ & $-0,89042$ & 0,258898 & $-3,43929$ & 0,013813 & \\
\hline \multirow{3}{*}{$\begin{array}{l}\text { Other } \\
\text { NACE } \\
\text { sectors }\end{array}$} & $\mathrm{AR}(1)$ & $-0,65882$ & 0,0919985 & $-7,1612$ & 0,002013 & \multirow{3}{*}{0,0012543} \\
\hline & $\mathrm{MA}(1)$ & 0,353004 & 0,153881 & 2,29401 & 0,083487 & \\
\hline & MA(2) & $-1,74936$ & 0,528752 & $-3,30848$ & 0,029696 & \\
\hline Households & \multicolumn{5}{|c|}{ Moving average of 2 terms } & - \\
\hline
\end{tabular}

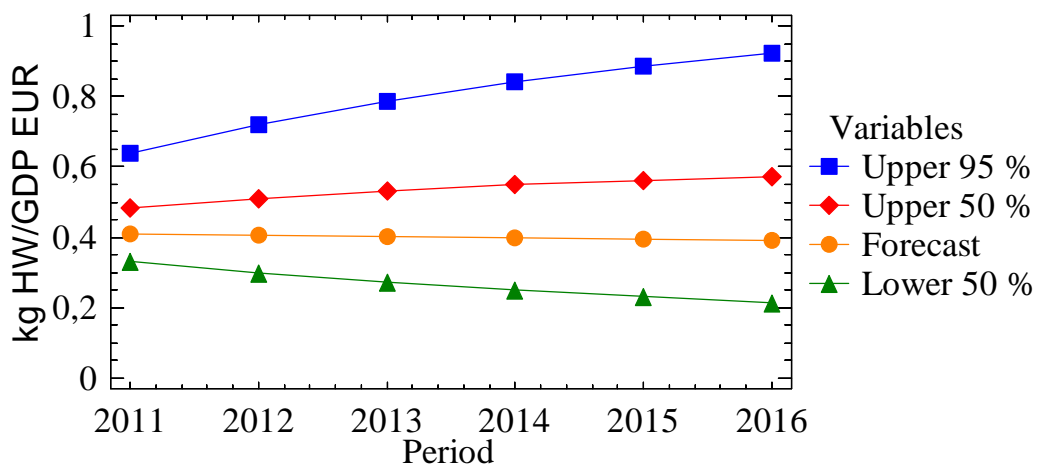

Figure 3: Summary of the forecast model for all NACE sectors and households.

sectors. The indicator takes into account the supply and demand tendencies and therefore accounts for the fact that increasing production rate will increase the total amount of HW. The indicative value should stay the same within the sector boundaries or even better if value declines. The introduced indicator is applicable tool for the development of waste management strategies and defining the indicative trajectories for the sector. The indicator can be applied also for benchmarking analysis within the level of sectors or companies. 


\section{Conclusions}

A new type of the indicator based on the HW intensity within the NACE Rev. 2 sectors and households has been developed. The indicator allows assessing the HW production intensity by taking into account a factor that increase in the production rate will trigger higher total amount of HW. The proposed indicator can be applied for the forecasting of future development of the HW intensity within the single sector and in the country. The indicator can be used for the benchmarking analysis of the single manufactures, same profile companies and same sectors in different countries. Moreover the indicator allows proposing measures for HW management system and allows monitoring of the development of HW production intensity. Developed methodology consists of 6 modules: historical data, assumptions, choose of indicators, data processing, and data analysis with STATGRAPHICS, and forecast models. The results of the study suggest that HW intensity in Latvia is forecasted to slowly decrease by $3.8 \%$ in next six years. The pessimistic prognosis (upper 95\%) gives an increase in $\mathrm{HW}$ intensity by $44.5 \%$, but intermediate (upper and lower $50 \%$ ) gives a corridor of $+18.4 \%$ to $-36.1 \%$.

\section{References}

[1] Letcher, T. M. and Vallero, D. A., Waste: A handbook for management, Elsevier Inc. Academic Press, pp. 604, 2011.

[2] European Commission, Report from the Commission to the Council and the European Parliament on the implementation of Council Regulation (EEC) No 259/93 of 1 February 1993 on the supervision and control of shipments of waste within, into and out of the European Community, and on the implementation of Regulation (EC) No 1013/2006 of 14 June 2006 on shipments of waste, Brussels, COM (2012) 448 final, pp. 11, 2012.

[3] European Environmental Agency, Material resources and waste, the European environment, state and outlook 2010, EEA, pp. 50, 2012.

[4] Weltens, R., Vanermen, G., Tirez, K., Robbens, J., Deprez, K. and Michiels, L., Screening tests for hazard classification of complex waste materials - Selection of methods, Waste Management, 32, pp. 2208-2217, 2012.

[5] Council Directive 91/689/EEC on hazardous waste, Official Journal of the European Communities, pp. 8, 1991.

[6] Wilke, B.-M., Riepert, F., Koch, C. and Kuhne, T., Ecotoxicological characterization of hazardous wastes, Ecotoxicology and Environmental Safety, 70, pp. 283-293, 2008.

[7] Giusti, L. A review of waste management practices and their impact on human health, Waste Management, 29, pp. 2227-2239, 2009.

[8] Musee, N., Lorenzen, L. and Aldrich, C., An aggregate fuzzy hazardous index for composite wastes, Journal of Hazardous Materials, A137, pp. 723-733, 2006. 
[9] Musee, N., Lorenzen, L. and Aldrich, C., New methodology for hazardous waste classification using fuzzy set theory. Part I. Knowledge acquisition, Journal of Hazardous Materials, 154, pp. 1040-1051, 2008.

[10] Musee, N., Lorenzen, L. and Aldrich, C., New methodology for hazardous waste classification using fuzzy set theory Part II. Intelligent decision support system, Journal of Hazardous Materials, 157, pp. 94-105, 2008.

[11] Das, A., Gupta, A.K. and Mazumder, T.N., Vulnerability assessment using hazard potency for regions generating industrial hazardous waste, Journal of Hazardous Materials, 209-210, pp. 308-317, 2012.

[12] Elimelech, E., Ayalon, O. and Flicstein, B., Hazardous waste management and weight-based indicators - the case of Haifa Metropolis, Journal of Hazardous Materials, 185, pp. 626-633, 2011.

[13] Moreira, A.M.M. and Gunther, W.M.R., Assessment of medical waste management at a primary health-care centre in São Paulo, Brazil, Waste Management, 33, pp. 162-167, 2013.

[14] Kiurski, J., Maric, B., Adamovic, D., Mihailovic, A., Grujic, S., Oros, I. and Kristic, J., Register of hazardous materials in printing industry as a tool for sustainable development management, Renewable and Sustainable Energy Reviews, 16, pp. 660-667, 2012.

[15] Yuan, H., Key indicators for assessing the effectiveness of waste management in construction projects, Ecological Indicators, 24, pp. 476484, 2013.

[16] Herva, M., Hernando, R., Carrasco, E.F. and Roca, E., Development of a methodology to assess the footprint of wastes, Journal of Hazardous Materials, 180, pp. 264-273, 2010.

[17] Streimikiene, D., Comparison of carbon dioxide and nuclear waste storage costs in Lithuania, Renewable and Sustainable Energy Reviews, 16, pp. 2434-2445, 2012.

[18] European Commission, Directive 2008/98/EC of the European Parliament and of the Council of 19 November 2008 on waste and repealing certain Directives, Official Journal of the European Union, pp. 28, 2008.

[19] Mazzanti, M., Is waste generation de-linking from economic growth? Empirical evidence in Europe, Applied Economics Sciences, 2, pp. 287291, 2008.

[20] Mazzanti, M. and Zoboli, R., Waste generation, waste disposal and policy effectiveness Evidence on decoupling from the European Union, Resources, Conservation and Recycling, 52, pp. 1221-1234, 2008.

[21] Sjöström, M. and Östblom, G., Decoupling waste generation from economic growth - A CGE analysis of the Swedish case, Ecological Economics, 69, pp. 1545-1552, 2010.

[22] Sjöström, M. and Östblom, G., Future waste scenarios for Sweden based on a CGE-model, working paper No. 109, National Institute of Economic Research, 2009.

[23] Yanrong, W., Cuili, W. and Han, W., Research on the Quantitative Relationship between the Generation of Industrial Solid Waste and Per Capita GDP of Henan Province, Energy Procedia, 5, pp. 593-597, 2011. 
[24] BiPRO, Screening of waste management performance of EU Member States. Report submitted under the EC project "Support to Member States in improving waste management based on assessment of Member States' performance”. Report prepared for the European Commission, European Commission, pp. 49, 2012.

[25] Lilja, R. and Liukkonen, S., Industrial hazardous wastes in Finland trends related to the waste prevention goal, Journal of Cleaner Production, 16, pp. 343-349, 2008.

[26] Court, C.D., Enhancing U.S. hazardous waste accounting through economic modelling, Ecological Economics, 83, pp. 79-89, 2012.

[27] The Ministry of Environmental protection and regional development, Atkritumu apsaimniekošanas valsts plāns 2013.-2020. gadam, pp. 86, 2012.

[28] Latvian Environment, Geology and Meteorology Centre. Database. Publiskās atskaites, 3 Atkritumi kopsavilkumi.

[29] Ministru kabineta noteikumi Nr.1075. Noteikumi par vides aizsardzības valsts statistikas pārskatu veidlapām. 22.12.2008. [27.01.2012.].

[30] Eurostat. Methodologies and Working papers, NACE Rev. 2, Statistical classification of economic activities in the European Community. Luxembourg: Office for Official Publications of the European Communities, pp. 369, 2008. 